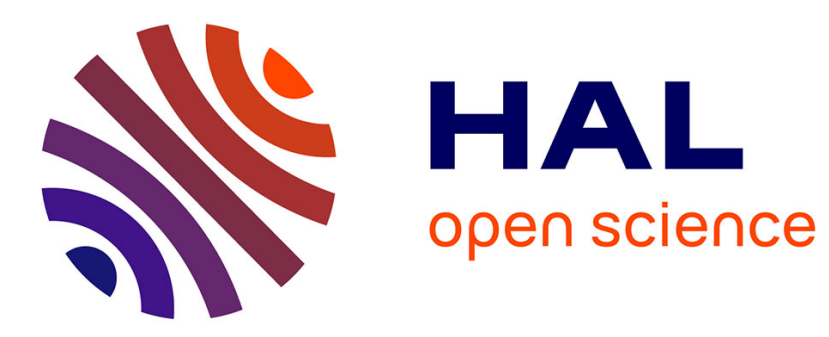

\title{
A Response to Richard Alba
}

\author{
Mary J. Hickman
}

\section{To cite this version:}

Mary J. Hickman. A Response to Richard Alba. Ethnicities, 2006, 6 (4), pp.542-546. 10.1177/146879680600600406 . hal-00571851

\section{HAL Id: hal-00571851 \\ https://hal.science/hal-00571851}

Submitted on 1 Mar 2011

HAL is a multi-disciplinary open access archive for the deposit and dissemination of scientific research documents, whether they are published or not. The documents may come from teaching and research institutions in France or abroad, or from public or private research centers.
L'archive ouverte pluridisciplinaire HAL, est destinée au dépôt et à la diffusion de documents scientifiques de niveau recherche, publiés ou non, émanant des établissements d'enseignement et de recherche français ou étrangers, des laboratoires publics ou privés. 


\title{
A response to Richard Alba
}

\author{
MARY J. HICKMAN
}

London Metropolitan University, UK

Richard Alba makes the case that the dearth of data about Catholic ethnics, for whom there are a number of reasons to seek information, is related both to the shift in focus to the greater disadvantages of women and of black and Asian minorities and to the cessation of interest in Catholic ethnics within sociology. This shift occurred once they were perceived as having accessed the middle class en masse. Alba takes Italian Americans as an exemplar and presents evidence of the possible underrepresentation of these groups on the faculties of elite American universities. The author contrasts the experiences of Catholic ethnics and Jewish Americans, citing the greater representation of the latter group among faculty at elite universities as the result of a collective struggle against anti-Semitism and collective experiences of mobility. He suggests that a prevailing pattern of individual mobility often involving self-presentation as emancipated from ethnic and religious traits contrived to work against the recognition of collective plight among Catholic ethnics.

Italian Americans are a useful and justifiable group to select in order to examine empirical data relating to the access of Catholic ethnics to the faculties of elite universities. The data examined reveal that Italian Americans form between 5 and 6 percent of the US population and are now between 4 and 5 percent of the professoriate in US universities. A comparison, which was restricted for greater rigour to US-born Italian-surnamed male professors, found that in elite universities they make up 1.9-2.6 percent of faculty compared with 3.3-3.6 percent among all male faculty. This suggests an underrepresentation in elite universities compared with all universities of the order of 30-40 percent and an even greater underrepresentation compared with the general population figures. There are problems, as detailed in Alba's account, in accessing data on Catholic ethnics. The above figures are therefore necessarily suggestive rather than definitive in conveying any underrepresentation. However, the argument would have been significantly strengthened, and/or more complex, if data on other prominent Catholic ethnic groups, to the extent these can be traced, had been included. In particular, the longer established Irish and German Catholic groups might have been contrasted with Poles as well as Italians, two emblematic groups in the 'new' immigrations to the US of the 1880 s to 1920 s. This might have teased out whether the underrepresentation of Italian Americans is typical of Catholic ethnics or specific. It might also have indicated whether, given the better picture presented for younger Italian Americans in the academy, we are witnessing the final throes, albeit 
of a much longer trajectory than has hitherto been assumed, of the eradication of prejudice towards Catholic ethnics.

Reference is made to the relatively better representation in elite faculties of Jewish Americans, many of whose ancestors immigrated from Europe in the same period of 'new' immigration as the largest phase of Italian immigrants. The discussion is therefore about differential progress among long-established European origin groups. This is worth exploring, as too often the discussion of the trajectories of recent post-1965 immigrant groups is based on a notion that apart from African Americans there has been a general levelling among all historical immigrant groups in the US. If this is not the case it is surely worth having our attention drawn to the differences that exist and suggesting explanations. But for a full picture of what accessing the faculty of elite universities might tell us about contemporary patterns of equality and mobility in the US, data about Catholic ethnics would have to be explicitly discussed in terms of what I assume is the underlying assumption of the article: that the groups who have the best and the worst chance of accessing elite university faculties are those who have been in America the longest. That is, for want of a better term, Anglo-Americans on the one hand and Native Americans and African Americans on the other hand. Bringing a range of historical groups together opens up a fuller discussion of diversity, and it seems important to always work across the white/black binary to address the intercutting cleavages of racial, ethnic and other hierarchies.

Alba's argument stimulates many questions and quite rightly highlights that accessing the middle class is not the end of the assimilation story. This last point particularly sparked my interest. Does the disappearance of interest in Catholic ethnics in sociology reflect assumptions about the class basis of the assimilation process for white ethnics? Or does it reflect the widespread acceptance of the 'ethnic options' thesis, even though that can be critiqued for its assumptions of relative homogeneity and for its rather static view of identifications and positionings upon arrival in the nirvana of American suburbia? Or maybe this absence reflects a general tendency among the intelligentsia of liberal, secular states to assign religion to the private sphere and castigate it as fundamentalist when it intrudes in the public sphere, and in the process ignore religion as an important component of multicultural societies for understanding both structural and identificational processes?

The idea that with the achievement of middle-class surburban status ethnicity becomes a lifestyle option, a costless form of community, whereas when it is correlated with class disadvantages it becomes a more complex phenomenon, seems to be uncontroversial. Today in the US, this complexity is deemed primarily to be a function of the racial/colour divide and, therefore, applies to African Americans and racialized groups among the post-1965 immigrants (Waters, 1990). This appears a surprisingly reductive 
orthodoxy given the long history of complex theorizing about the assimilatory trajectories of European immigrants to the US. Labour historians, historians of racial identity and historians of immigrant ethnic groups have all elaborated revised assessments of assimilatory processes in recent decades. Perhaps what is really required is not only that these different groups of historians talk together (Kazal, 1995) but also that there should be a more interdisciplinary exchange, especially between sociology and history. Catholic ethnics are a critical group for whom the suburbanization thesis is thought to apply. My criticism does not stem from thinking it to be wrong in general outline but from thinking that the way this thesis has been appropriated tends to elide internal differentiations based, for example, on social class and generation, and the role of religion is not fully explored, as the article under review would seem to point.

Another interesting and it would seem pertinent issue raised by Alba is that stereotypes of Jews include that of a 'diabolical' cleverness while, whether they are Irish, Polish or Italian in origin, Catholic ethnics were stereotyped as stupid (as well as specific variants for each group). At one level, the explanation of this difference, and also the backdrop to the issues the data on Italian-American access to membership of elite university faculties raise in Alba's view, lies in the long history of endemic antiCatholicism in American intellectual, social and cultural life. From the intensely celebrated Pope Days in 17th- and 18th-century Boston (on 5 November each year, transporting to another context what in England is Guy Fawkes Day celebrating the saving of the king, James I, from a Catholic plot in 1605), to the formation of the Republican Party in the mid-19th century, to one of the main appeals of the American Protective Association in the 1890s and of the Klu Klux Klan in the 1920s, anti-Catholicism was as constant a thread as race, one with which it was intertwined, in the formation and reconfigurations of the Union. It is easy to forget that the liberal, ultimately secularized, Protestantism that was/is the dominant ideological discourse of the United States was forged against Catholicism. Hostility to an ultramontane Catholic Church was articulated in terms of its supposed opposition to modernity and autonomous individualism. Catholic immigrants were positioned as ignorant dupes of a machiavellian organization, as for example in Friedrich Knapp's assessment in 1871 that 'the Irish element is the rank and file, which are pushed back and forward, like the pawns on a chessboard at the will of players in Rome' (quoted in McGreevy, 2003: 99). Little credit for independent thought was attributed to such pawns then or for many years to come.

Another question Alba's argument raised for me was: what does it take for ethnonational differences to be transcended and for collective action to be produced based on religio-cultural similarity? This happens, or has happened in the past, in many different contexts. Alba's argument is that this did not occur among Catholic ethnics in the same way as it did among 
the various Jewish groups that immigrated to the US. Another facet of the same discussion could be to explore the 'handicap' of belonging to a particular branch of Christianity in a nation founded on another, Protestantism. Is in fact the relative underrepresentation of Catholic ethnics on the faculties of elite universities a consequence of the inbetween position' of Catholics, the result of a form of subordinated inclusion? Have Catholics imitated the values and mores of the dominant Protestant elite to ascend the rungs of an ethnically and racially stratified society, rather than hammered down the door to gain admittance and recognition of their abilities? This could amount to the disadvantages, or advantages, of a despised similarity. Being white may have assisted the social mobility of (European) Catholic ethnics in the long term, but for the many post-1965 Catholic immigrants from Mexico, Latin America, Africa and the Philippines their respective multi-positionalities will have to be addressed in order to assess the specific significance of religion, class, ethnicity and race for each grouping.

None of these reasons - entry to the middle class, apparent fading of antiCatholicism, longevity of presence - seem good enough reasons to have lost interest in the trajectory of Catholic ethnics or in their significance for relations between religion, class, gender, ethnicity and race more generally. The United States of America was built on a foundational racial cleavage but it was not solely built on this bedrock. A variety of familial and social hierarchies have been the pillars and struts of the state and civic society (Hill Collins, 2000). Understanding the intersections of these various props and their relative strengths in different periods is one of the main tasks of interdisciplinary study of the formation of the US and of contemporary heterogeneities. Catholic ethnics are hardly hegemonic in the US, there has after all only been one Catholic president and no Jewish president (rather similar to the situation in Britain where there has been one Jewish and no Catholic prime minister), let alone an African-American or a woman president. In fact, Episcopalians and Presbyterians make up 47.2 percent of all presidents and represent 20.2 percent of the population, while, if one adds in Methodists and Baptists, the four groups comprise 66.2 percent of all presidents and are 22.5 percent of the general population (statistics from http://www.adherents.com). These four religions emanate largely from the original English, Scottish, Welsh and Irish Protestant settlements. So at the elite levels of US institutions there is something to be addressed as to the inadequacy of their representativeness of the nation as a whole, even including groups thought to be thoroughly assimilated, such as Catholic ethnics. Although it should be noted that with Samuel Alito confirmed as a member of the Supreme Court the membership is 56 percent Roman Catholic, driven by a conservative alliance on abortion and other matters.

There is, of course, a very real danger of essentializing ethnic and racial categories. It is arguable with intermarriage rates as they are between 
European ethnic groups, and as they increase between European and Asians groups and to a lesser extent Hispanic groups, that it is impossible to chart the trajectory of different ethnic groups. It has always been debatable that intermarriage has led to assimilation rather than to new hybridities. Nonetheless, it seems valuable to readdress religion and ethnicity per se, and for the historical European immigrant groups in particular, because at the very least it is a reminder of two things. First that entry to the middle class is not the sole determinant of acceptability and integration. Second, that the US national identity based on a liberal, secularized Protestantism was forged in part by its centuries-long encounter with Catholicism, combined with a powerful anti-Semitism, and now asserts itself against an Islam that it similarly demonizes.

\section{References}

Hill Collins, Patricia (2000) 'Race Rhetoric in the US: A Family Affair', Ethnic and Racial Studies Annual Lecture, London School of Economics, 8 June.

Kazal, Russell A. (1995) 'Revisiting Assimilation: The Rise, Fall, and Reappraisal of a Concept in American Ethnic History', American Historical Review 100: 437-71.

McGreevy, John T. (2003) Catholicism and American Freedom: A History, London and New York: W.W. Norton.

Waters, Mary (1990) Ethnic Options: Choosing Identities in America. Berkeley: University of California Press.

MARY J. HICKMAN is Professor of Irish Studies and Sociology, and Director of the Institute for the Study of European Transformations and the Irish Studies Centre, London Metropolitan University. Address: ISET, London Metropolitan University, Tower Building, 166-220 Holloway Road, London N7 8DB, UK. [email: mary.hickman@londonmet.ac.uk]

\section{Diversity's blind spot or the data's blind spot?}

\section{DOUGLAS S. MASSEY}

Princeton University

In 'Diversity's Blind Spot', my good friend Richard Alba argues that one subgroup of Americans has consistently been overlooked in assessing the nation's progress in achieving broader inclusion and representation in 